\title{
PENGARUH INTENSITAS KOMPETISI PASAR TERHADAP HUBUNGAN ANTARA PENGGUNAAN INFORMASI SISTEM AKUNTANSI MANAGEMEN DAN KINERJA UNIT BISNIS DAN KEPUASAN KERJA
}

\author{
YULIUS KURNIA SUSANTO \\ Trisakti School of Management \\ siou_chiang@yahoo.com \\ GUDONO \\ Universitas Gadjah Mada
}

\begin{abstract}
This research examines the moderating effect of the intensity of market competition on the relationship between the usefulness of management accounting systems (MAS) information and business unit performance and job satisfaction. Fifty six business unit managers from manufacturing industry in Java and Sumatera had participated in this research. The collecting data used a questionnaire survey via electronicmail and post. Data were analyzed using a two-way analysis of variance. The results showed that the effects of the usefulness of MAS information on business unit performance and job satisfaction were dependent on the intensity of market competition. Under high levels of the intensity of market competition, the usefulness of sophisticated MAS information had a positive effect on business unit performance and job satisfaction, but under low levels it had a negative effect.
\end{abstract}

Keywords: $\quad$ MAS information, Intensity of market competition, Business unit performance and Job satisfaction.

\section{PENDAHULUAN}

Banyak perubahan terjadi dalam lingkungan bisnis seperti perubahan teknologi produksi dan teknologi informasi serta globalisasi mengakibatkan organisasi untuk terus berkembang dalam mencapai tujuan organisasi di tengah-tengah persaingan bisnis yang semakin ketat. Dalam keadaan ini para pembuat keputusan merasakan bahwa desain 
sistem akuntansi managemen (SAM) semakin penting sehingga perencanaan SAM yang merupakan bagian dari sistem pengendalian managemen mendapat perhatian.

Salah satu alat yang digunakan managemen untuk membantu menghadapi persaingan bisnis adalah sistem akuntansi managemen yang merupakan fasilitas fungsi pendukung yang menghasilkan informasi yang relevan dan tepat waktu untuk perencanaan, pengendalian, pembuatan keputusan dan evaluasi kinerja (Gordon dan Miller 1976). Informasi ini memungkinkan managemen untuk mengimplementasikan strategi dan melakukan aktivitas operasional yang diperlukan untuk mencapai tujuan organisasi secara keseluruhan.

Beberapa penelitian akuntansi managemen menggunakan pendekatan kontinjensi yang digunakan untuk mengevaluasi faktor-faktor eksternal organisasi (seperti intensitas kompetisi pasar, perubahan teknologi organisasi, dan ketidakpastian lingkungan) yang diduga dapat menyebabkan SAM menjadi lebih efektif (Gul 1991, Faisal 2006). Beberapa penelitian sebelumnya berusaha mengidentifikasikan variabel-variabel kontekstual seperti perceived environmental uncertainty (PEU) (Gul 1991), desentrali-sasi dan PEU (Gul dan Chia 1994), ketidakpastian tugas (Chong 1996), strategi dan PEU (Chong dan Chong 1997), intensitas kompetisi pasar (Mia dan Clarke 1999), ketidakpastian lingkungan dan struktur organisasi (Supardiyono 1999), strategi bisnis dan ketidakpastian lingkungan (Desmiyawati 2001), ketidakpastian tugas (Azmi 2003), PEU (Agbejule 2005), ketidakpastian tugas dan budaya organisasi (Nurnaluri 2005), serta intensitas persaingan pasar, strategi dan PEU (Faisal 2006) yang semuanya mungkin mempengaruhi hubungan antara informasi SAM dan kinerja serta kepuasan kerja.

Peneliti menggunakan intensitas kompetisi pasar sebagai variabel kontekstual dalam mempengaruhi hubungan antara penggunaan informasi SAM dan variabel outcome seperti kinerja dan kepuasan kerja. Alasan peneliti menggunakan variabel intensitas kompetisi pasar adalah pertama, kompetisi pasar telah menciptakan pergolakan, tekanan, risiko dan ketidakpastian perusahaan. Kedua, puncak tuntutan perusahaan yaitu menjawab segala ancaman dan kesempatan dalam lingkungan berkompetisi dengan mendesain serta menggunakan sistem pengendalian yang tepat untuk mencapai tujuan. Ada sejumlah bukti empiris yang mendukung pengaruh intensitas kompetisi pasar terhadap hubungan antara penggunaan informasi SAM dan kinerja perusahaan (seperti Bromwich 1990, Mia dan Clarke 1999).

Bromwich (1990) berpendapat bahwa informasi SAM membantu perusahaan menghadapi tantangan pasar kompetitif yang berfokus pada peningkatan nilai tambah perusahaan agar melebihi kompetitornya. Kesesuaian antara informasi SAM dengan kebutuhan pembuat keputusan akan meningkatkan kualitas keputusan yang akan diambil dan pada akhirnya akan meningkatkan kinerja unit bisnis. Hasil penelitian Mia dan Clarke (1999) menyatakan bahwa penggunaan informasi SAM dapat membantu perusahaan untuk mengimplementasikan rencana-rencana mereka dalam merespon lingkungan bersaingnya. Sedangkan penelitian lain yang menggunakan variabel intensitas kompetisi pasar dengan konteks yang bebeda adalah penelitian Chong et al. (2001) yang menyebutkan bahwa intensitas kompetisi pasar mempengaruhi hubungan antara partisipasi anggaran dan kinerja managerial serta kepuasan kerja. Hasil penelitian-penelitian tersebut menunjukkan bahwa intensitas kompetisi pasar yang 
merupakan faktor eksternal perusahaan dapat mempengaruhi hubungan antara penggunaan informasi SAM dan kinerja unit bisnis serta kepuasan kerja.

Tujuan penelitian ini adalah pertama, peneliti ingin menemukan bukti empiris apakah perusahaan yang menggunakan informasi sistem akuntansi managemen (SAM) yang sesuai dengan lingkungan persaingan akan memiliki kinerja dan kepuasan kerja yang lebih baik daripada mereka yang tidak menggunakan informasi SAM yang sesuai dengan lingkungan persaingan. Kedua, peneliti ingin lebih memahami faktor-faktor yang mempengaruhi kinerja unit bisnis dan kepuasan kerja. Ketiga, peneliti ingin memperdalam teori kontinjensi pada penelitian desain SAM, khususnya penggunaan variabel kontekstual (seperti intensitas kompetisi pasar) yang mempengaruhi hubungan antara penggunaan informasi SAM dan kinerja unit bisnis serta kepuasan kerja.

Penelitian ini memberikan kontribusi kepada perancang organisasi agar mempertimbangkan kondisi ketidakpastian (seperti intensitas kompetisi pasar) untuk mendesain dan mengimplementasikan suatu sistem akuntansi managemen yang menyediakan informasi dalam rangka mempermudah pengambilan keputusan dan mengevaluasi aktivitas managerial yang pada akhirnya akan meningkatkan kinerja managerial, kepuasan kerja dan kinerja unit bisnis.

Penelitian ini disusun dengan urutan penulisan sebagai berikut berupa pendahuluan menjelaskan mengenai latar belakang masalah, tujuan penelitian, kontribusi penelitian dan organisasi penulisan. Telaah literatur dan pengembangan hipotesis berisi teori kontinjensi, informasi sistem akuntansi managemen, dan pengaruh intensitas kompetisi pasar terhadap hubungan antara informasi SAM dan kinerja unit bisnis serta kepuasan kerja. Metoda penelitian terdiri atas pemilihan sampel dan pengumpulan data, definisi operasional dan pengukuran variabel. Selanjutnya hasil penelitian yang berisi uji validitas dan reliabilitas, serta pengujian hipotesis. Simpulan, keterbatasan dan rekomendasi untuk penelitian-penelitian berikutnya.

\section{TELAAH LITERATUR DAN PENGEMBANGAN HIPOTESIS}

\section{Teori Kontinjensi}

Pendekatan kontinjensi pada sistem akuntansi managemen berdasarkan pada premis umum bahwa tidak ada sistem akuntansi managemen secara universal yang selalu tepat untuk dapat diterapkan pada seluruh organisasi dalam setiap keadaan akan tetapi SAM bergantung pada faktor-faktor situasional dalam organisasi (Otley 1980). Simons (1987) mengidentifikasi hubungan ini sebagai suatu prasyarat untuk mengembangkan teoritis desain SAM. Telah banyak penelitian yang menerapkan teori kontinjensi untuk menganalisis dan merancang sistem pengendalian (Otley 1980) khususnya di bidang sistem akuntansi managemen yang dihubungkan dengan variabel-variabel kontekstual seperti ketidakpastian lingkungan (Gordon dan Narayanan 1984), kompleksitas teknologi (Chenhall dan Morris 1986), strategi bisnis (Simons 1987, Abernethy dan Guthrie 1994, Chong dan Chong 1997), perceived Environmental Uncertainty (PEU) (Gul 1991), ketidakpastian tugas (Chong 1996), intensitas kompetisi pasar (Mia dan Clarke 1999) dan strategic uncertainty (Riyanto 2003). 
Pendekatan kontinjensi banyak menarik minat peneliti karena mereka ingin mengetahui apakah tingkat keandalan sistem akuntansi managemen itu akan selalu berpengaruh sama terhadap kinerja pada setiap kondisi atau tidak. Dengan berdasarkan pada tingkat kontinjensi tersebut, ada dugaan bahwa terdapat faktor-faktor kontekstual yang akan saling berinteraksi selaras dengan kondisi tertentu yang dihadapi. Peneliti akan menunjukkan ringkasan hasil penelitian terdahulu yang menjadi acuan dalam penelitian ini yang dapat dilihat pada Tabel 1 sebagai berikut:

TABEL 1

Review Hasil Penelitian

\begin{tabular}{|c|c|c|}
\hline Peneliti & Model & Hasil \\
\hline Gul (1991) & $\stackrel{\text { PEU }}{\stackrel{\downarrow}{\longrightarrow} \text { KAMerja Managerial }}$ & $\begin{array}{l}\text { Dalam kondisi ketidakpastian ling- } \\
\text { kungan tinggi, MAS akan mening- } \\
\text { katkan kinerja akan tetapi dalam } \\
\text { kondisi ketidakpastian lingkungan } \\
\text { rendah akan menurunkan kinerja. }\end{array}$ \\
\hline $\begin{array}{l}\text { Chong } \\
\text { (1996) }\end{array}$ & $\begin{array}{l}\text { SAM } \underset{\uparrow}{\longrightarrow} \text { Kinerja Managerial } \\
\text { Ketidakpastian Tugas }\end{array}$ & $\begin{array}{l}\text { Dalam kondisi ketidakpastian tugas } \\
\text { yang tinggi, penggunaan informasi } \\
\text { SAM yang berkarakterisitik broad } \\
\text { scope menghasilkan keputusan ma- } \\
\text { nagerial yang efektif dan memper- } \\
\text { baiki kinerja managerial. }\end{array}$ \\
\hline $\begin{array}{l}\text { Mia \& Clarke } \\
\text { (1999) }\end{array}$ & $\begin{array}{l}\text { Intensitas Kompetisi Pasar } \\
\text { Informasi SAM } \\
\text { Kinerja Unit Bisnis }\end{array}$ & $\begin{array}{l}\text { Penggunaan informasi SAM } \\
\text { memediasi hubungan antara } \\
\text { intensitas kompetisi pasar dan } \\
\text { kinerja unit bisnis. }\end{array}$ \\
\hline $\begin{array}{l}\text { Supardiyono } \\
\text { (1999) }\end{array}$ & $\begin{array}{l}\text { Ketidakpastian Lingkungan } \\
\text { SAM } \stackrel{\downarrow}{\longrightarrow} \text { Kinerja Managerial } \\
\text { Struktur Organisasional } \\
\text { SAM } \stackrel{\downarrow}{\longrightarrow} \text { Kinerja Managerial }\end{array}$ & $\begin{array}{l}\text { Sistem akuntansi managemen akan } \\
\text { meningkatkan kinerja managerial } \\
\text { pada PEU tinggi dan menurunkan } \\
\text { kinerja managerial pada PEU } \\
\text { rendah. }\end{array}$ \\
\hline
\end{tabular}




\begin{tabular}{|c|c|c|}
\hline $\begin{array}{l}\text { Chong et al. } \\
\text { (2001) }\end{array}$ & $\begin{array}{l}\text { Intensitas Kompetisi Pasar } \\
\text { Partisipasi Anggaran } \stackrel{\downarrow}{\longrightarrow} \\
\text { Kinerja }\end{array}$ & $\begin{array}{l}\text { Semakin tinggi intensitas kompetisi } \\
\text { pasar maka partisipasi anggaran } \\
\text { akan meningkatkan kinerja dan } \\
\text { kepuasan kerja. }\end{array}$ \\
\hline $\begin{array}{l}\text { Azmi } \\
\text { (2003) }\end{array}$ & $\begin{array}{l}\text { SAM } \underset{\text { Ketidakpastian Tugas }}{\longrightarrow} \text { Kinerja Managerial } \\
\text { Sula }\end{array}$ & $\begin{array}{l}\text { Semakin tinggi ketidakpastian tugas, } \\
\text { maka penggunaaan informasi SAM } \\
\text { yang berkarakterisitk broad scope } \\
\text { akan meningkatkan kinerja mana- } \\
\text { gerial. }\end{array}$ \\
\hline $\begin{array}{l}\text { Desmiyawati } \\
\text { (2001) }\end{array}$ & Strategi Bisnis & $\begin{array}{l}\text { - Karakterisitik informasi SAM } \\
\text { broad scope akan lebih mening- } \\
\text { katkan kinerja untuk organisasi } \\
\text { bertipe strategi prospektor dari- } \\
\text { pada defendor. } \\
\text { - Karakterisitik informasi SAM } \\
\text { broad scope akan lebih mening- } \\
\text { katkan kinerja pada kondisi ke- } \\
\text { tidakpastian lingkungan tinggi } \\
\text { daripada ketidakpastian ling- } \\
\text { kungan rendah. }\end{array}$ \\
\hline $\begin{array}{l}\text { Agbejule } \\
\text { (2005) }\end{array}$ & SAM $\stackrel{\text { PEU }}{\longrightarrow}$ Kinerja Managerial & $\begin{array}{l}\text { Dalam kondisi ketidakpastian ling- } \\
\text { kungan tinggi, MAS akan mening- } \\
\text { katkan kinerja tetapi dalam kondisi } \\
\text { ketidakpastian lingkungan rendah } \\
\text { akan menurunkan kinerja. }\end{array}$ \\
\hline
\end{tabular}

Sumber: Review penelitian (2007)

\section{Informasi Sistem Akuntansi Managemen}

Atkinson et al. (1995) mengungkapkan bahwa akuntansi managemen menghasilkan informasi yang berguna untuk membantu manager dalam membuat keputusan yang lebih baik. Secara tradisional informasi akuntansi managemen didominasi oleh informasi keuangan tetapi dalam perkembangan informasi nonkeuangan juga menentukan (Banker et al. 2000). Penyediaan informasi yang layak meningkatkan pemahaman terhadap permasalahan dan mengurangi ketidakpastian yang terjadi karena kesenjangan antara informasi yang dibutuhkan dengan yang tersedia 
dalam pengambilan keputusan (Galbraith 1973) dalam Agbejule (2005). Peneliti sistem akuntansi managemen (SAM) mendefinisikan SAM sebagai suatu sistem formal yang didesain untuk menyediakan informasi dalam rangka mempermudah pengambilan keputusan dan mengevaluasi aktivitas managerial (Chenhall 2003).

Hasil penelitian Chenhall dan Morris (1986) menemukan bukti empiris tentang karakteristik informasi SAM yang bermanfaat yaitu broad scope, timeliness, aggregation dan informasi yang terintegrasi (ringkasan karakteristik informasi SAM dapat dilihat pada Tabel 2). Dalam penelitian Gul (1991) dan Agbejule (2005) keempat karakterisitik informasi SAM diinteraksikan dengan perceived environmental uncertainty yang mempengaruhi kinerja managerial.

TABEL 2

Karakteristik Informasi SAM

\begin{tabular}{ll}
\hline Dimensi & \multicolumn{1}{c}{ Subdimensi } \\
\hline Broad Scope & Informasi eksternal \\
\cline { 2 - 2 } & Informasi nonkeuangan \\
\cline { 2 - 2 } & Informasi yang berorientasi ke masa yang akan datang \\
\hline Timeliness & Frekuensi pelaporan \\
\cline { 2 - 2 } & Kecepatan pelaporan \\
\hline Aggregation & Aggregate perioda waktu \\
\cline { 2 - 2 } & Aggregate area fungsional \\
\cline { 2 - 2 } Integration & Analisis atau model keputusan \\
& Target tepat untuk aktivitas dan hubungan timbal balik- \\
\cline { 2 - 2 } & nelaporam sub-unit \\
\hline
\end{tabular}

Sumber: Chenhall dan Morris (1986)

\section{Pengaruh Intensitas Kompetisi Pasar Terhadap Hubungan Antara Informasi SAM dan Kinerja Unit Bisnis dan Kepuasan Kerja}

Gordon dan Narayan (1984) menyebutkan bahwa informasi sistem akuntansi managemen (SAM) mempunyai peranan penting untuk pengambilan keputusan jika dihubungkan dengan kondisi lingkungan yang tidak pasti. Hal ini juga didukung oleh Chenhall dan Morris (1986) yang menyebutkan bahwa ada hubungan antara informasi SAM yang berkarakterisitik broad scope dan timeliness dan ketidakpastian lingkungan.

Intensitas kompetisi pasar merupakan salah satu faktor ketidakpastian lingkungan (Gul 1991). Semakin intensif kompetisi pasar, organisasi akan meningkatkan differensiasi produk, penurunan siklus hidup produk, memperkenalkan saluran baru, menghadapi peningkatan sensitivitas pasar, serta meningkatkan target produk (Rolfe 1992). Perubahan tersebut menciptakan tantangan kompetitif sehingga unit bisnis akan mengadopsi strategi termasuk diferensiasi produk, pelayanan dan harga (Linn 1994). 
Mia dan Clarke (1999) menyebutkan bahwa kompetisi pasar mempengaruhi penggunaan informasi SAM yang dapat meningkatkan kinerja unit bisnis. Berdasarkan hasil-hasil penelitian tersebut dapat disimpulkan bahwa manager yang menghadapi situasi ketidakpastian seperti kompetisi pasar, informasi SAM yang digunakan sebagai dasar pengambilan keputusan akan meningkatkan kinerja unit bisnis dan kepuasan kerja.

SAM merupakan sistem informasi yang mengumpulkan data keuangan dan nonkeuangan yang kemudian data tersebut diproses, disimpan dan dilaporkan kepada manager untuk dasar pengambilan keputusan. SAM juga merupakan bagian integral dari suatu organisasi yang berkaitan dengan struktur dan proses organisasi untuk menghasilkan pengendalian organisasi termasuk pengendalian manager. SAM dan sistem pengendalian yang baik bagi organisasi dipengaruhi oleh intensits kompetisi pasar. Perbedaan tipe kompetisi (harga, saluran pemasaran dan produk) mempunyai pengaruh yang berbeda terhadap penggunaan informasi SAM dan sistem pengendalian organisasi. Manager menggunakan informasi SAM untuk pengambilan keputusan tentang product pricing, forecasting permintaan pasar, market planning, pembelian bahan baku, product palanning dan peningkatan infrastruktur organisasi (Mia dan Clarke 1999).

Penelitian-penelitian sebelumnya memberikan bukti empiris bahwa penggunaan informasi SAM yang sophisticated lebih bermanfaat ketika menghadapi situasi ketidakpastian yang tinggi seperti intensitas kompetisi pasar (Gordon dan Narayanan 1984, Chenhall dan Morris 1986, Gul 1991). Dalam kondisi intensitas kompetisi pasar yang tinggi, manager memerlukan informasi SAM yang sophisticated untuk membuat keputusan yang lebih tepat sehingga meningkatkan kinerja unit bisnis. Sedangkan untuk menghadapi intensitas kompetisi pasar yang rendah, informasi akuntansi tradisional atau informasi SAM yang less sophisticated lebih tepat digunakan oleh manager untuk pengambilan keputusan. Apabila manager menggunakan informasi SAM yang sophistticated untuk mengahadapi kondisi intensitas kompetisi pasar yang rendah maka kinerja unit bisnis menurun. Hal tersebut disebabkan oleh informasi SAM yang digunakan terlalu berlebihan (Gul 1991). Dengan demikian bahwa dalam kondisi intensitas kompetisi pasar tinggi penggunaan informasi SAM yang sophisticated akan meningkatkan kinerja unit bisnis akan tetapi dalam kondisi intensitas kompetisi pasar rendah akan menurunkan kinerja unit bisnis. Pengembangan hipotesis dapat diringkas pada Tabel 3 sebagai berikut:

TABEL 3

Pengembangan Hipotesis

Pengaruh Penggunaan Informasi SAM Terhadap Kinerja Unit Bisnis Yang Dimoderasi Oleh Intensitas Kompetisi Pasar

Intensitas Kompetisi Pasar

\begin{tabular}{lll}
\hline Informasi SAM & Rendah & Tinggi \\
\hline
\end{tabular}




\begin{tabular}{lll}
\hline Less Sophisticated & Kinerja unit bisnis tinggi & Kinerja unit bisnis rendah \\
\hline Sophisticated & Kinerja unit bisnis rendah & Kinerja unit bisnis tinggi \\
\hline
\end{tabular}

Berdasarkan Tabel 3 maka dapat dibuat hipotesis sebagai berikut:

$\mathrm{H}_{1}$ : Semakin tinggi intensitas kompetisi pasar maka penggunaan informasi SAM yang sophisticated akan meningkatkan kinerja unit bisnis.

Model penelitian dapat dilihat pada Gambar 1 sebagai berikut:

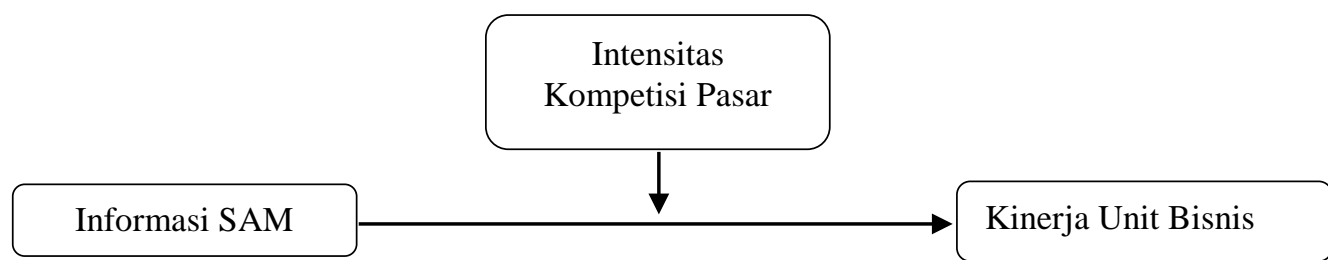

GAMBAR 1

Pengaruh Penggunaan Informasi SAM Terhadap Kinerja Unit Bisnis Yang Dimoderasi Oleh Intensitas Kompetisi Pasar

Kepuasan kerja didefinisikan sebagai sikap seseorang terhadap pekerjaannya (Dewar dan Werbel 1979). Sikap itu berasal dari persepsi mereka tentang pekerjaanya. Kepuasan kerja seseorang dapat berasal dari tingkat ketersediaan sumber daya organisasi untuk mendukung perkerjaan seperti ketersediaan informasi untuk mendukung suatu pengambilan keputusan. Informasi yang merupakan hasil dari suatu SAM (seperti informasi nonekonomik, informasi yang tepat waktu, informasi untuk analisis kenaikan laba dan informasi yang terintegrasi) digunakan oleh manager organisasi untuk mengambil suatu keputusan dalam berbagai situasi seperti intensitas kompetisi pasar.

Tingkat kesesuaian antara ketersediaan informasi SAM dan intensitas kompetisi pasar dapat menimbulkan suatu persepsi kepuasan manager terhadap pekerjaannya. Apabila manager dihadapkan pada kondisi tingginya intensitas kompetisi pasar maka penggunaan informasi SAM yang sophisticated untuk pengambilan keputusan dapat menimbulkan perasaan puas dalam bekerja. Dengan demikian bahwa dalam kondisi intensitas kompetisi pasar tinggi penggunaan informasi SAM yang sophisticated akan meningkatkan kepuasan kerja akan tetapi dalam kondisi intensitas kompetisi pasar rendah akan menurunkan kepuasan kerja. Pengembangan hipotesis dapat diringkas pada Tabel 4 sebagai berikut: 
TABEL 4

Pengembangan Hipotesis

Pengaruh Penggunaan Informasi SAM Terhadap Kepuasan Kerja Yang Dimoderasi Oleh Intensitas Kompetisi Pasar

\begin{tabular}{lcc}
\hline & \multicolumn{2}{c}{ Intensitas Kompetisi Pasar } \\
\hline Informasi SAM & Rendah & Tinggi \\
\hline Less Sophisticated & Kepuasan kerja tinggi & Kepuasan kerja rendah \\
\hline Sophisticated & Kepuasan kerja rendah & Kepuasan kerja tinggi \\
\hline
\end{tabular}

Berdasarkan Tabel 4 maka dapat dibuat hipotesis sebagai berikut:

$\mathrm{H}_{2}$ : Semakin tinggi intensitas kompetisi pasar maka penggunaan informasi SAM yang sophisticated akan meningkatkan kepuasan kerja.

Model penelitian dapat dilihat pada Gambar 2 sebagai berikut:

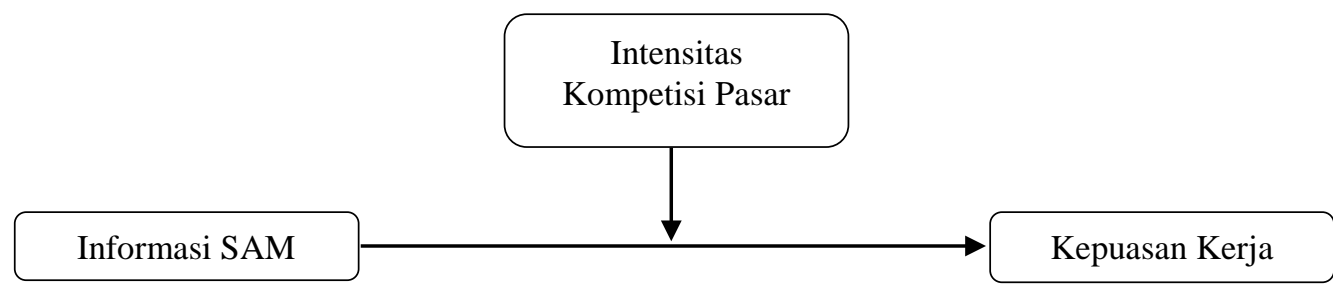

GAMBAR 2

Pengaruh Penggunaan Informasi SAM Terhadap Kepuasan Kerja Yang Dimoderasi Oleh Intensitas Kompetisi Pasar

\section{METODE PENELITIAN}

\section{Pemilihan Sampel dan Pengumpulan Data}

Sampel penelitian diambil dari industri-industri manufaktur dan jasa sektor bank yang terdaftar di Indonesian capital market directory (ICMD) tahun 2003 secara purposive. Responden penelitian adalah manager unit bisnis untuk industri manufaktur, alasan pemilihan responden adalah karena mereka merupakan manager-manager unit bisnis yang melakukan aktivitas rutin dan kinerjanya diukur dengan pencapaian target masing-masing. Unit bisnis dapat didefinisikan sebagai sebuah organisasi atau bagian dari organisasi yang mempunyai aktivitas rutin seperti bagian pemasaran, produksi, keuangan, personalia dan research and development (Mia dan Clarke 1999). Pengumpulan data menggunakan survai kuisioner melalui electronic-mail dan pernah dipraktikkan dalam penelitian Achyari (2000) dan Jumaili (2006). Pengumpulan data juga menggunakan jasa pos. Jumlah kuisioner yang dikirimkan kepada responden 
sebanyak lima ratus tiga puluh kuisioner dan yang dapat diolah sebanyak lima puluh enam kuisioner. Jumlah tersebut dianggap telah memenuhi syarat untuk mengolah data dan mewakili populasi dalam penelitian ini serta sesuai dengan respon rate penelitianpenelitian di Indonesia sebelumnya yang tergolong rendah yaitu sebesar sepuluh persen sampai dengan enambelas persen (Mardiyah dan Gudono 2001).

\section{Definisi Operasional dan Pengukuran Variabel}

\section{Informasi Sistem Akuntansi Managemen}

Sistem Akuntansi Managemen (SAM) adalah sistem informasi yang mengumpulkan data operasional dan keuangan, memproses, menyimpan dan melaporkan kepada pengguna (Atkinson et al. 1995). Informasi SAM diukur dengan menggunakan instrumen sembilan belas item dengan tujuh poin skala likert yang dikembangkan oleh Chenhall dan Morris (1986). Para responden diminta untuk meranking ketersediaan informasi SAM pada unit bisnisnya. Angka satu merepresentasikan informasi SAM tidak tersedia dan angka tujuh merepresentasikan informasi SAM tersedia sangat banyak (lihat lampiran 1).

\section{Intensitas Kompetisi Pasar}

Intensitas kompetisi pasar didefinisikan sebagai faktor-faktor yang mempengaruhi tingkat persaingan yang diukur dari jumlah pesaing utama yang beroperasi dalam pasar, frekuensi tingkat perubahan teknologi dalam industri, frekuensi pengenalan produk baru, tingkat pemotongan harga, berbagai rangkaian kesepakatan dengan pelanggan jika dibandingkan dengan pesaing, perubahan kebijakan pemerintah dan pengurangan tarif seperti pajak, intensitas kompetisi harga, intensitas kompetisi produk (differentiation), promosi produk dan saluran distribusi (Khandawalla 1972, Chong et al. 2001). Variabel ini diukur dengan menggunakan instrumen yang yang dikembangkan oleh Chong et al. (2001) yang diadopsi dari Mia dan Clarke (1999) dan penelitian Khandawalla (1972). Instrumen ini berisi empat pertanyaan menyangkut intensitas kompetisi pasar dengan menggunakan tujuh poin skala likert (lihat lampiran 2). Angka satu merepresentasikan kondisi kompetisi pasar yang sangat rendah dan angka tujuh merepresentasikan kondisi kompetisi pasar yang sangat tinggi.

\section{Kinerja Unit Bisnis}

Kinerja unit bisnis didefinisikan oleh Mia dan Clarke (1999) sebagai seberapa tinggi tingkat pencapaian target yang telah direncanakan, misalnya pencapaian produksi, kos, kualitas, pengiriman produk, service atau pelayanan, volume penjualan, pangsa pasar dan tingkat laba. Variabel ini diukur dengan instrumen yang dikembangkan oleh Mia dan Clarke (1999) dengan tujuh poin skala likert. Instrumen ini berisi delapan item pertanyaan yang menyangkut kinerja organisasi. Para responden diminta untuk menilai rata-rata kinerja unit bisnis mereka dibandingkan dengan rata-rata kinerja unit bisnis 
lainnya yang sejenis. Angka satu merepresentasikan kinerja di bawah rata-rata dan angka tujuh merepresentasikan kinerja di atas rata-rata.

\section{Kepuasan Kerja}

Kepuasan kerja didefinisikan sebagai bentuk kepuasan individu akan pekerjaannya serta bentuk kesukaan akan bekerja dalam suatu organisasi (Chong et al. 2001). Kepuasan kerja diukur dengan dua item pertanyaan dengan tujuh poin skala likert yang dikembangkan oleh Dewar dan Werbel (1979). Instrumen ini telah digunakan oleh penelitian akuntansi sebelumnya (Chong et al. 2001). Angka satu merepresentasikan tidak puas dan angka tujuh merepresentasikan sangat puas (lihat lampiran 3).

\section{HASIL PENELITIAN}

\section{Uji Validitas dan Reliabilitas}

Uji validitas bertujuan untuk memastikan bahwa masing-masing pertanyaan akan terklarifikasi pada variabel-variabel yang telah ditentukan. Butir-butir pertanyaan akan mempunyai validitas tinggi apabila pertanyaan-pertanyaan tersebut dapat mengukur apa yang seharusnya diukur. Uji validitas menggunakan analisis faktor dengan tujuan untuk mengetahui kevalidan butir-butir pertanyaan untuk masing-masing variabel atau untuk mengetahui validitas konstruk (Chenhall dan Morris 1986). Masing-masing instrumen diharapkan memiliki nilai Kaiser's MSA (Measure of sampling adequacy) lebih dari 0,5 sehingga data yang dikumpulkan dapat dikatakan tepat untuk analisis faktor (Kaiser dan Rice 1974) dalam Rustiana (2000). Nilai eigenvalue-nya harus lebih dari satu dan masing-masing butir pertanyaan dari setiap variabel diharapkan memiliki factor loading lebih dari 0,4 sesuai dengan rule of thumb.

Setelah dilakukan uji validitas kemudian pertanyaan tersebut diuji dengan uji reliabilitas atau konsistensi internal yang bertujuan untuk mengetahui sejauh mana pengukuran yang telah dilakukan dalam penelitian ini dapat dipercaya atau diandalkan. Konsistensi hasil pengukuran mengindikasikan bahwa instrumen tersebut dapat bekerja dengan baik pada waktu yang berbeda dan situasi yang berbeda (Cooper dan Schindler 2003). Uji reliabilitas dilakukan dengan cara menghitung nilai cronbach alpha dari masing-masing instrumen dalam suatu variabel. Nilai cut off untuk menentukan reliabilitas suatu instrumen adalah nilai cronbach alpha lebih dari 0,5 (Nunnally 1967). Hasil uji validitas dan reliabilitas menunjukkan bahwa data yang digunakan dalam penelitian ini valid (akurat) dan reliabel (dapat diandalkan) yang dapat dilihat pada Tabel 5 sebagai berikut: 
TABEL 5

Hasil Uji Validitas dan Reliabilitas

\begin{tabular}{|c|c|c|c|c|}
\hline Variabel & Pertanyaan & $\begin{array}{l}\text { Koefisien } \\
\text { Cronbach } \\
\text { Alpha }\end{array}$ & $\begin{array}{c}\text { Kaiser's } \\
\text { MSA }\end{array}$ & $\begin{array}{l}\text { Factor } \\
\text { Loading }\end{array}$ \\
\hline \multirow{3}{*}{$\begin{array}{l}\text { Informasi SAM } \\
\text { broad scope } \\
\text { timeliness } \\
\text { aggregation }\end{array}$} & $2,6,8,11,16 a, 16 b$ & 0,759 & 0,665 & $0,561-0,914$ \\
\hline & $4,10,15,19$ & 0,623 & 0,655 & $0,589-0,808$ \\
\hline & $\begin{array}{l}\text { 1a,1b,3,7,9,12a,12b,12c, } \\
\text { 12d,14,17 }\end{array}$ & 0,866 & 0,764 & $0,559-0,856$ \\
\hline integration & $5,13,18$ & 0,681 & 0,646 & $0,729-0,827$ \\
\hline $\begin{array}{l}\text { Intensitas } \\
\text { Kompetisi Pasar }\end{array}$ & $\begin{array}{l}\text { 20a,20b,20c,20d, } \\
\text { 20e,20f,21,22,23 }\end{array}$ & 0,793 & 0,677 & 0,656-0,765 \\
\hline Kinerja Unit Bisnis & $24,25,26,27,28,29,30,31$ & 0,792 & 0,757 & $0,607-0,877$ \\
\hline Kepuasan Kerja & 32,33 & 0,697 & 0,5 & 0,876 \\
\hline
\end{tabular}

Sumber: Hasil Pengolahan Data

\section{Pengujian Hipotesis}

Hipotesis diuji dengan menggunakan two-way analysis of variance (ANOVA). ANOVA merupakan salah satu metoda untuk menguji hubungan antara dua variabel yang salah satu variabelnya merupakan variabel nonmetrik atau kategorikal. ANOVA digunakan untuk mengetahui pengaruh utama (main effect) dan pengaruh interaksi (interaction effect) dari variabel independen terhadap variabel dependen. Statistika deskriptif untuk semua variabel yang diukur disajikan dalam Tabel 6 sebagai berikut:

TABEL 6

Statistika Deskriptif

\begin{tabular}{lccccc}
\hline \multicolumn{1}{c}{ Variabel } & Mean & $\begin{array}{c}\text { Standard } \\
\text { Deviation }\end{array}$ & Median & $\begin{array}{c}\text { Actual } \\
\text { Range }\end{array}$ & $\begin{array}{c}\text { Theoretical } \\
\text { Range }\end{array}$ \\
\hline $\begin{array}{l}\text { Informasi sistem akun- } \\
\text { tansi managemen (SAM) }\end{array}$ & 4,6257 & 0,7784 & 4,7292 & $2,63-6,17$ & $1-7$ \\
$\begin{array}{l}\text { Intensitas Kompetisi } \\
\text { Pasar }\end{array}$ & 4,6230 & 0,8070 & 4,5556 & $2,22-6,22$ & $1-7$ \\
Kinerja Unit Bisnis & 4,9152 & 0,5509 & 4,7500 & $4,00-6,38$ & $1-7$ \\
Kepuasan Kerja & 5,0179 & 0,8144 & 5,0000 & $3,00-7,00$ & $1-7$ \\
\hline
\end{tabular}

Sumber: Hasil Pengolahan Data

Sebelum menguji hipotesis, peneliti akan melihat apakah ada perbedaan karakteristik sampel (dilihat dari karakteristik informasi sistem akuntansi managemen broad scope, timeliness, aggregation, integration, intensitas kompetisi pasar, kinerja unit bisnis dan kepuasan kerja) antara responden yang merespon melalui electronic-mail 
dan pos. Hasil independent-samples $t$ test yang terlihat pada Tabel 7 menunjukkan bahwa tidak ada perbedaan karakteristik sampel antara responden yang merespon melalui e-mail dan pos.

TABEL 7

Independent-Samples T Test

\begin{tabular}{|c|c|c|c|c|c|c|}
\hline \multirow[b]{2}{*}{ Variabel } & \multicolumn{2}{|c|}{ E-mail $(n=38)$} & \multicolumn{2}{|c|}{ Pos $(n=18)$} & \multirow[b]{2}{*}{$t$} & \multirow[b]{2}{*}{ p-value } \\
\hline & Mean & $\begin{array}{l}\text { Standard } \\
\text { Deviation }\end{array}$ & Mean & $\begin{array}{l}\text { Standard } \\
\text { Deviation }\end{array}$ & & \\
\hline $\begin{array}{l}\text { Informasi sistem akun- } \\
\text { tansi managemen (SAM) }\end{array}$ & 4,6711 & 0,83725 & 4,5301 & 0,64831 & 0,629 & 0,266 \\
\hline $\begin{array}{l}\text { Intensitas kompetisi } \\
\text { pasar }\end{array}$ & 4,6959 & 0,87629 & 4,4691 & 0,63149 & 0,982 & 0,165 \\
\hline Kinerja unit bisnis & 4,9737 & 0,60065 & 4,7917 & 0,41569 & 1,158 & 0,126 \\
\hline Kepuasan kerja & 5,0263 & 0,89252 & 5,0000 & 0,64169 & 0,112 & 0,455 \\
\hline
\end{tabular}

Sumber: Hasil Pengolahan Data

\section{Pengujian hipotesis 1}

Untuk menginterpretasikan hasil signifikansi interaksi dua arah, informasi SAM dan intensitas kompetisi pasar, keduanya didikotomisasi berdasarkan nilai mediannya untuk mendapatkan empat subsampel terpisah dari kinerja unit bisnis. Hasilnya dipresentasikan pada Tabel 9 dan Gambar 3. Pengujian yang menggunakan ANOVA harus memenuhi asumsi bahwa variabel dependen memiliki varian yang sama dalam setiap grup yang dibentuk oleh variabel independen kategori (homogeneity of variance). Untuk menguji homogeneity of variance menggunakan uji levene's test. Hasil uji levene's test untuk pengujian hipotesis satu menunjukkan bahwa nilai $\mathrm{F}_{3,52}$ sebesar 1,656 dan tidak signifikan pada $p$-value $0,05(p=0,188)$ yang berarti bahwa asumsi ANOVA terpenuhi.

Hasil pengujian hipotesis satu terlihat pada pengaruh interaksi antara informasi SAM dan intensitas kompetisi pasar yang bernilai positif $(\mathrm{F}=6,057)$ dan signifikan pada $p$-value dibawah $0,05(p=0,017)$ yang terlihat pada Tabel 8 sehingga hipotesis satu terdukung. Hipotesis satu juga didukung oleh nilai rata-rata kinerja unit bisnis yang paling besar $(5,25)$ terletak pada grup 4 dengan informasi SAM yang sophisticated dan intensitas kompetisi pasar yang tinggi yang terlihat pada Tabel 9 dan Gambar 3. Terdukungnya hipotesis satu menunjukkan bahwa dalam kondisi intensitas kompetisi pasar tinggi penggunaan informasi SAM yang sophisticated akan meningkatkan kinerja unit bisnis akan tetapi dalam kondisi intensitas kompetisi pasar rendah akan menurunkan kinerja unit bisnis (lihat nilai mean kinerja unit bisnis pada grup 4 lebih besar daripada nilai mean kinerja unit bisnis pada grup 3 yaitu 5,2500> 4,6964, lihat Tabel 9). Hasil pengujian hipotesis satu mengindikasikan 
bahwa semakin tinggi intensitas kompetisi pasar, maka penggunaan informasi SAM yang sophisticated akan meningkatkan kinerja unit bisnis.

TABEL 8

Tests of Between-Subjects Effects

(untuk kinerja unit bisnis)

\begin{tabular}{lcccc}
\hline \multicolumn{1}{c}{ Pengaruh } & $\boldsymbol{d} \boldsymbol{f}$ & $\begin{array}{c}\text { Mean } \\
\text { Square }\end{array}$ & $\boldsymbol{F}$-Ratio & $\boldsymbol{p}$-value \\
\hline Konstanta & 1 & 1000,71 & 4396.682 & 0,000 \\
Informasi SAM & 1 & 1,306 & 5,739 & 0,020 \\
Intensitas kompetisi pasar & 1 & 0,423 & 1,857 & 0,179 \\
Informasi SAM x Intensitas & 1 & 1,379 & $\mathbf{6 , 0 5 7}$ & $\mathbf{0 , 0 1 7}$ \\
kompetisi pasar & 3 & 1,618 & 7,111 & 0,000 \\
Corrected model & 52 & 0,228 & - & - \\
Error & 56 & - & - & - \\
Total & & & & \\
\hline
\end{tabular}

Adjusted $\mathrm{R}^{2}=0,250$

TABEL 9

Nilai Rata-rata, Deviasi Standar dan Frekuensi Kinerja Unit Bisnis Untuk Informasi SAM Yang Sophisticated (Less Sophisticated) dan Intensitas Kompetisi Pasar Yang Tinggi (Rendah)

\begin{tabular}{|c|c|c|}
\hline & $\begin{array}{c}\text { Intensitas kompetisi pasar } \\
\text { rendah }\end{array}$ & $\begin{array}{c}\text { Intensitas kompetisi pasar } \\
\text { tinggi }\end{array}$ \\
\hline $\begin{array}{l}\text { Informasi SAM yang } \\
\text { less sophisticated }\end{array}$ & $\begin{aligned} \text { (Grup 1) } \overline{Y k u} & =4,7059 \\
S_{Y k u} & =0,4049 \\
\mathrm{n} & =17\end{aligned}$ & $\begin{aligned}(\text { Grup 2) } \overline{Y k u} & =4,5469 \\
\mathrm{~S}_{\mathrm{Yku}} & =0,4578 \\
\mathrm{n} & =8\end{aligned}$ \\
\hline $\begin{array}{l}\text { Informasi SAM yang } \\
\text { sophisticated }\end{array}$ & $\begin{aligned} \text { (Grup 3) } \overline{Y k u} & =4,6964 \\
S_{Y k u} & =0,4137 \\
n & =7\end{aligned}$ & $\begin{aligned} \overline{Y k u} & =5,2500 \\
S_{Y k u} & =0,5405 \\
n \quad & =24\end{aligned}$ \\
\hline
\end{tabular}

ku = kinerja unit bisnis 


\section{Estimated Marginal Means of ykur}

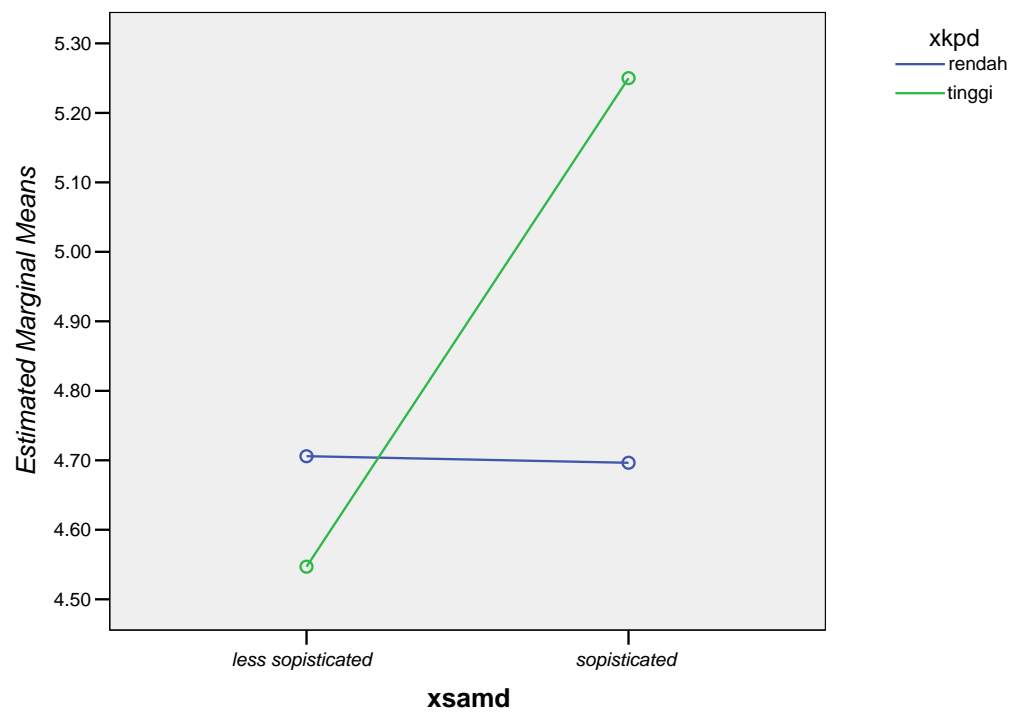

GAMBAR 3

Interaksi Dua Arah Antara Informasi SAM dan Intensitas Kompetisi Pasar Yang Mempengaruhi Kinerja Unit Bisnis

\section{Pengujian hipotesis 2}

Untuk menginterpretasikan hasil signifikansi interaksi dua arah, informasi SAM dan intensitas kompetisi pasar, keduanya didikotomisasi berdasarkan nilai mediannya untuk mendapatkan empat subsampel terpisah dari kepuasan kerja. Hasilnya dipresentasikan pada Tabel 11 dan Gambar 4. Hasil uji levene's test untuk pengujian hipotesis dua menunjukkan bahwa nilai $\mathrm{F}_{3,52}$ sebesar 1,708 dan tidak signifikan pada $p$ value 0,05 ( $p=0,177)$ yang berarti bahwa asumsi ANOVA terpenuhi.

Hasil pengujian hipotesis dua terlihat pada pengaruh interaksi antara informasi SAM dan intensitas kompetisi pasar yang bernilai positif $(F=10,227)$ dan signifikan pada $p$-value dibawah $0,01(p=0,002)$ yang terlihat pada Tabel 10 sehingga hipotesis dua terdukung. Hipotesis dua juga didukung oleh nilai rata-rata kepuasan kerja yang paling besar $(5,4583)$ terletak pada grup 4 dengan informasi SAM yang sophisticated dan intensitas kompetisi pasar yang tinggi yang terlihat pada Tabel 11 dan Gambar 4. Terdukungnya hipotesis dua menunjukkan bahwa dalam kondisi intensitas kompetisi pasar tinggi penggunaan informasi SAM yang sophisticated akan meningkatkan kepuasan kerja akan tetapi dalam kondisi intensitas kompetisi pasar rendah akan menurunkan kepuasan kerja (lihat nilai mean kepuasan kerja pada grup 4 lebih besar daripada nilai mean kepuasan kerja pada grup 3 yaitu 5,4583>4,7143, lihat Tabel 11). Hasil pengujian hipotesis dua mengindikasikan bahwa semakin tinggi 
intensitas kompetisi pasar, maka penggunaan informasi SAM yang sophisticated akan meningkatkan kepuasan kerja.

TABEL 10

Tests of Between-Subjects Effects

(untuk kepuasan kerja)

\begin{tabular}{lrrrc}
\hline \multicolumn{1}{c}{ Pengaruh } & $\boldsymbol{d} \boldsymbol{f}$ & $\begin{array}{c}\text { Mean } \\
\text { Square }\end{array}$ & F-Ratio & p-value \\
\hline Konstanta & 1 & 1011,768 & 2011,804 & 0,000 \\
Informasi SAM & 1 & 2,938 & 5,842 & 0,019 \\
Intensitas kompetisi pasar & 1 & 0,034 & 0,067 & 0,796 \\
Informasi SAM x Intensitas & 1 & 5,143 & $\mathbf{1 0 , 2 2 7}$ & $\mathbf{0 , 0 0 2}$ \\
kompetisi pasar & 3 & 3,444 & 6,847 & 0,001 \\
Corrected model & 52 & 0,503 & - & - \\
Error & 56 & - & - & - \\
Total & & & &
\end{tabular}

Adjusted $\mathrm{R}^{2}=0,242$

TABEL 11

Nilai Rata-rata, Deviasi Standar dan Frekuensi Kepuasan Kerja Untuk Informasi SAM Yang Sophisticated (less Sophisticated) dan Intensitas Kompetisi Pasar Yang Tinggi (rendah)

\begin{tabular}{|c|c|c|}
\hline & $\begin{array}{l}\text { Intensitas kompetisi } \\
\text { pasar rendah }\end{array}$ & $\begin{array}{c}\text { Intensitas kompetisi } \\
\text { pasar tinggi }\end{array}$ \\
\hline $\begin{array}{l}\text { Informasi SAM yang } \\
\text { less sophisticated }\end{array}$ & $\begin{array}{r}\text { (Grup 1) } \overline{Y k k}=4,8824 \\
S_{Y k k}=0,4851 \\
n \quad=17\end{array}$ & (Grup 2) $\begin{aligned} \overline{Y k k} & =4,2500 \\
\mathrm{~S}_{\mathrm{Ykk}} & =0,6547 \\
\mathrm{n} & =8\end{aligned}$ \\
\hline $\begin{array}{l}\text { Informasi SAM yang } \\
\text { sophisticated }\end{array}$ & $\begin{aligned} \text { (Grup 3) } \overline{Y k k}=4,7143 \\
S_{Y k k}=0,6986 \\
n \quad=7\end{aligned}$ & $\begin{aligned}(\text { Grup 4) } \overline{Y k k}=5,4583 \\
S_{\mathrm{Ykk}}=0,8459 \\
n=24\end{aligned}$ \\
\hline
\end{tabular}

$k k=$ kepuasan kerja 
Estimated Marginal Means of $y k k r$
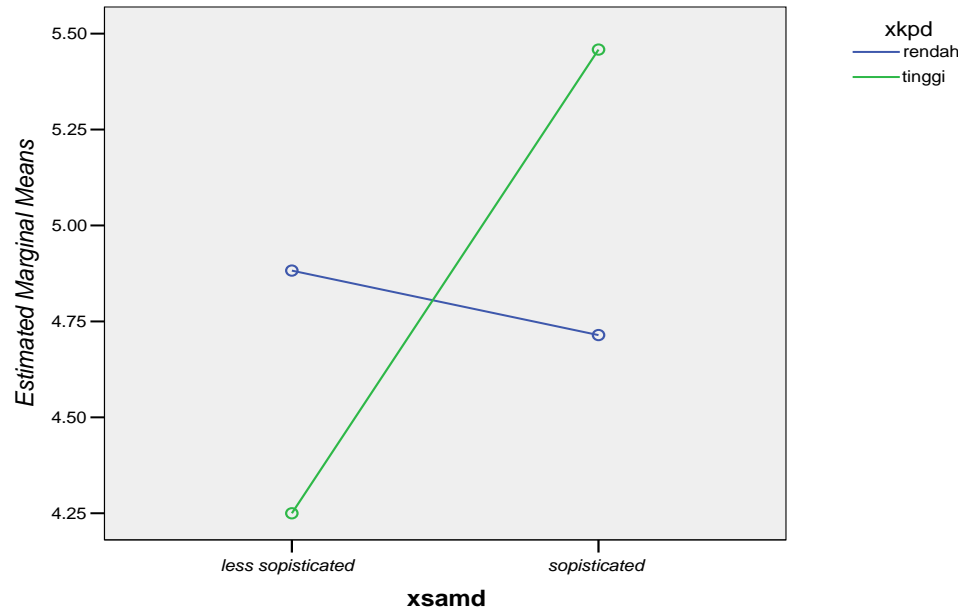

GAMBAR 4

Interaksi Dua Arah Antara Informasi SAM dan Intensitas Kompetisi Pasar Yang Mempengaruhi Kepuasan Kerja

\section{SIMPULAN, KETERBATASAN DAN REKOMENDASI}

Penelitian ini memberikan bukti empiris bahwa dalam kondisi intensitas kompetisi pasar tinggi penggunaan informasi SAM yang sophisticated akan meningkatkan kinerja unit bisnis dan kepuasan kerja akan tetapi dalam kondisi intensitas kompetisi pasar rendah akan menurunkan kinerja unit bisnis dan kepuasan kerja. Penelitian ini berhasil mengkonfirmasi hasil penelitian Mia dan Clarke (1999) dan Chong et al. (2001).

Penelitian ini memiliki beberapa keterbatasan yang mungkin dapat mengganggu hasil penelitian antara lain:

1. Penelitian ini hanya fokus pada penggunaan karakteristik informasi sistem akuntansi managemen (SAM) broad scope, timeliness, aggregation dan integration. Penelitian Agbejule (2005) menguji modifikasi antara keempat dimensi SAM yang mempengaruhi kinerja managerial (seperti modifikasi antara informasi SAM broad scope dan aggregation; antara informasi SAM broad scope, aggregation dan integration; antara informasi SAM timeliness dan aggregation; antara informasi SAM broad scope dan integration).

2. Pengumpulan data dengan menggunakan metoda survai yang dikirimkan melalui electronic-mail dan pos. Kuisioner yang dikirimkan melalui mailing list pada yahoo groups dan melalui pos, ada kemungkinan diisi oleh responden yang tidak diharapkan. Hal tersebut dapat menjadi kelemahan dalam penelitian ini. 
3. Pengambilan sampel penelitian yang hanya berasal dari industri manufaktur menyebabkan kurang bervariasinya persepsi sampel. Sifat yang homogen ini akan mempengaruhi hasil penelitian.

4. Manager unit bisnis yang perusahaaannya memiliki kinerja yang kurang baik ada kecenderungan untuk tidak berpartisipasi dalam penelitian ini. Hal ini terbukti dengan adanya kuisioner yang tidak direspon.

Dari beberapa keterbatasan yang dikemukakan di atas, hasil penelitian ini diharapkan dapat mendorong penelitian-penelitian berikutnya. Penelitian yang akan dilakukan berikutnya diharapkan dapat memperbaiki keterbatasan penelitian ini dengan mempertimbangkan beberapa faktor antara lain:

1. Model penelitian ini dapat menjelaskan variansi kinerja unit bisnis dan kepuasan kerja masing-masing adalah 25 persen (lihat adjusted $\mathrm{R}^{2}$ pada Tabel 8) dan 24,2 persen (lihat adjusted $\mathrm{R}^{2}$ pada Tabel 10). Hal ini menunjukkan bahwa masih ada variabel lain yang dapat mempengaruhi kinerja unit bisnis dan kepuasan kerja selain informasi SAM dan intensitas kompetisi pasar. Contoh variabel lain tersebut adalah customization produk (Bouwens dan Abernethy 2000), locus of control (Chong dan Eggleton 1996) dan gaya kepemimpinan (Jiambalvo dan Pratt 1982).

2. Perlunya sampel yang berbeda yang tidak hanya mengambil sampel dari industri manufaktur, tetapi juga industri jasa dan dagang.

3. Melakukan survai dengan wawancara langsung terhadap manager unit bisnis, sehingga dapat diperoleh responden dan tingkat respon yang benar-benar diharapkan.

\section{REFERENSI:}

Abernethy, M. A. dan Guthrie, C. H. 1994. An Empirical Assessment of the "fits" Between Strategy and Management Information System Design. Accounting and Finance, Vol.34, pp.49-66.

Achyari, Didi. 2000. Pemanfaatan Internet untuk Riset dan Implikasi terhadap Riset Akuntansi. Jurnal Ekonomi dan Bisnis Indonesia 15 (2), pp.257-267.

Agbejule, Adebayo. 2005. The Relationship between Management Accounting Systems and Perceived Environmental Uncertainty on Managerial Performance: A Research Note. Accounting and Business Research, Vol.15, No.4, pp.295-305.

Atkinson, AA., RJ Banker, RS. Kaplan dan SM. Young. 1995. Management Accounting. Englewood Cliftts, New Jersey: Prrentice-Hall.

Azmi, Zul. 2003. Pengaruh Ketidakpastian Tugas terhadap hubungan antara Karakteristik Sistem Akuntansi Managemen dan Kinerja Mangerial. Thesis (tidak dipublikasikan), Program Pasca Sarjana UGM, Jogjakarta.

Banker, RD., Gordon, P. dan Dhinu, Srinivasan. 2000. An Empirical Investigation of an Incentive Plan that Includes Nonfinancial Performance Measures. The Accounting Review, Vol.75, No.1, pp.65-92.

Bouwens, J. dan Abernethy, MA. 2000. The Consequences of Customization on Management Accounting System Design. Accounting, Organization and Society, Vol.25, pp.221-241.

Bromwich, M. 1990. The Case for Strategic Management Accounting: The Role of Accounting information for Strategy in Competitive Markets. Accounting Organization and Society.Vol. 15. pp.27-46.

Chenhal, RH. dan Morris, D. 1986. The Impact of Structure, Environment, and Interdependence on Perceived Usefulness of Management Accounting Systems. The Accounting Review, Vol.61, pp.16-35. 
Chenhall, RH. 2003. Management Control System design within its organizational context. Findings form contingency-based research and directions for future. Accounting, Organization and Society, Vol.28, pp.127-168.

Chong, VK. 1996. Management Accounting Systems, Task Uncertainty and Managerial Performance: A Research Note. Accounting, Organization and Society, Vol.21, pp.415-421.

Chong, VK. dan Ian RC. Eggleton. 1996. Management Accounting Systems design and its Interaction with Task Uncertainty and Locus of control on Managerial Performance.

Chong, V.K dan Kar Ming Chong. 1997. Strategic Choices, Environmental Uncertainty and SBU Performance: A Note of the Intervening Role of Management Accounting Systems. Accounting and Business Research, Vol. 27 No.4. pp.268-276.

Chong, VK., Ian RC. Eggleton dan Michele Leong. 2001. The Impact of Market Competition and Budgetary Participation on Performance and Job Satisfaction: Evidence from The Australian Banking and Financial Services Sectors. The 2000 Asian-Pacific Conference on International Accountting Issues, Beijing, China.

Cooper, Donald R. dan Pamela S. Schindler. 2003. Busines Research Methods. Eight Edition, New York: McGraw-Hill Companies, Inc.

Desmiyawati. 2001. Pengaruh Strategi Bisnis dan Ketidakpastian Lingkungan terhadap Hubungan antara Karakteristik Informasi Broad Scope Sistem Akuntansi Manajemen dengan Kinerja Organisasi. Thesis (tidak dipublikasikan), Program Pasca Sarjana UGM, Jog-jakarta.

Dewar, R. dan Werbel, J. 1979. Universalistic and contingency predictions of employee satisfaction and conflict. Administrative Science Quarterly, pp. 313-327.

Faisal. 2006. Analisis Pengaruh Intensitas Persaingan dan Variabel Kontekstual terhadap Penggunaan Informasi Sistem Akuntansi Manajemen dan Kinerja Unit Bisnis dengan Pendekatan Partial Least Square. Simposium Nasional Akuntansi IX.

Gordon, LA. dan Miller, D. 1976. A Contingentigency Framework For The Design Of Accounting Information System. Accounting, Organization and Society, Vol.1, pp.59-69.

Gordon, LA. dan Narayan, VK. 1984. Management Accounting Systems, Perceived Environmental Uncertainty and Organizational Structure: an Empirical Investigation. Accounting, Organization and Society, Vol.9, pp.33-47.

Ghozali, Imam. 2005. Aplikasi Analisis Multivariate dengan Program SPSS. Edisi Ketiga. Semarang: Badan Penerbit Universitas Diponegoro.

Gul, FA. 1991. The Effect of Managements Accounting Systems, Perceived Environmental Uncertainty on Small Business Managerial Performance. Accounting and Business Research, Vol.22, pp.57-61.

Gul, FA. dan Yew, MC. 1994. The Effect of Managements Accounting Systems, Perceived Environmental Uncertainty and Decentralization on Managerial Performance: A Test of ThreeWay Interaction. Accounting Organization and Society, Vol.19, No.4/5, pp. 413-426.

Hair, J.F., Anderson, R.E., dan Black, W.C. 2006. Multivariate Data Analysis. Sixth Edition. New Jersey: Prentice Hall International, Inc.

Iselin, E. R. 1988. The Effect of Information Load and Information Diversity on Decision Quality in the Structured Decision Task. Accounting, Organization and Society, 13(2). pp.147-164.

Jiambalvo, J. dan Pratt, J. 1982. Task Complexity and Leadership Effectiveness in CPA Firms. The Accounting Review, Vol.57, No.4.

Khandawalla, P. 1972. The Effect of Diffrent Types of Competition on the Use of Management Control. Journal of Accounting Research. pp.275-285.

Luthans, Fred. 1998. Organizational Behavior. Eight Edition: Irwin McGrawHill.

Linn, T.A. 1994. Learning from the Competition, Journal of Accountancy. February, pp.43-46.

Mahoney, TA., TH. Jerdee dan SJ. Carroll. 1963. Development of Managerial Performance: A Research Approach. Cincinnati: South Western Publ. Co.

Mardiyah, Aida Ainul dan Gudono. 2001. Pengaruh Ketidakpastian Lingkungan dan Desentralisasi terhadap karakteristik Sistem Akuntansi Managemen. Jurnal Riset Akuntansi Indonesia 4(1). pp.1-30.

Mia, L dan Brian Clarke. 1999. Market Competition, Management Accounting Systems and Business Unit Performance. Management Accounting Research, Vol.10. pp.137-158.

Mulyadi dan Johny Setyawan. 1999. Sistem Perencanaan dan Pengendalian, Sistem Pelipatgandaan Kinerja Perusahaan. Edisi 1, Yogyakarta: Aditya Media. 
Nizarudin, Abu. 2006. Pengaruh Strategi Customization terhadap Kinerja Perusahaan melalui Penggunaan Karakteristik Informasi Sistem Akuntansi Manajemen yang Bersifat Broad Scope dan Aggregation. Simposium Nasional Akuntansi IX.

Nunnally, J. 1967. Pycometric Theory. New York: McGraw-Hill.

Nurnaluri, Srithi. 2005. Ketidakpastian Tugas dan Budaya Organisasi sebagai Variabel Pemoderasi terhadap hubungan antara penggunaan Informasi Akuntansi dengan Kinerja Managerial. Thesis (tidak dipublikasikan), Program Pasca Sarjana UGM, Jogjakarta.

Otley. 1980. The Contigency Theory of Management Accounting: Achievement and Prognosis. Accounting Organization and Society, Vol.5, No.4, pp.413-428.

Porter, M.E. 1980. How Competitive Forces Shape Strategy. Harvard Business Review. March/April. pp.137-145.

Riyanto, Bambang. 1999. Identifikasi Isu Penelitian Akuntansi Manajemen: Pendekatan Kontinjensi. Media Akuntansi, No.34/Th.VI April.

Riyanto, Bambang. 2003. An Examination of the Impact of the Fit between Strategic Uncertainty and Management Accounting Systems on Financial Performance. Jurnal Riset Akuntansi Indonesia, Vol.6, No.3, September, pp.288-303.

Rolfe, A.J. 1992. Profitability, Reporting Techniques Bridge Information Gap. The Journal of Business Strategy. pp.32-37.

Sekaran, Uma. 2003. Research Methods for Business: A Skill-Building Approach. Fourth Edition. New York: John Wiley \& Sons, Inc.

Simons, R. 1987. Accounting Control Systems and Business Strategy: An Empirical Analysis. Accounting, Organization and Society, Vol.12, No.4, pp.357-374.

Supardiyono, YP. 1999. Pengaruh Ketidakpastian Lingkungan dan Struktur Organisasi terhadap Efektifitas Sistem Akuntansi Managemen dalam peningkatan Kinerja Managerial. Thesis (tidak dipublikasikan), Program Pasca Sarjana UGM, Jogjakarta.

\section{Lampiran 1}

\section{Instrumen Informasi Sistem Akuntansi Managemen}

Sumber: Chenhall dan Morris (1986)

\section{Broad scope}

1. Informasi mengenai faktor-faktor eksternal Unit bisnis, seperti kondisi ekonomi, pertumbuhan penduduk, dan perkembangan teknologi.

2. Informasi nonekonomik, seperti selera pelanggan, sikap karyawan, relasi kerja, sikap pemerintah, lembaga konsumen, dan ancaman pesaing.

3. Informasi tentang perhitungan kemungkinan terjadinya suatu peristiwa di masa yang akan datang, seperti estimasi probabilitas.

4. Informasi yang berhubungan dengan kejadian-kejadian di masa yang akan datang.

5. Informasi nonkeuangan yang berkaitan dengan bidang-bidang berikut:

a. Informasi berorientasi internal seperti efisiensi, tingkat output, dan absensi karyawan.

b. Informasi pasar seperti pangsa pasar, pertumbuhan, dan sebagainya.

\section{Timeliness}

1. Informasi yang diberikan pada Anda secara otomatis atau segera sesaat setelah informasi selesai diproses.

2. Tidak terdapat penundaan waktu antara peristiwa yang terjadi dengan pemberian informasi yang relevan dengan Anda (Jika terdapat penundaan waktu maka tandailah angka 1.) 
3. Informasi yang dibutuhkan segera tersedia ketika diminta.

4. Laporan sering disediakan secara sistematis dan teratur, seperti laporan harian, laporan mingguan, dan laporan bulanan (Jika laporan jarang tersedia maka tandailah angka 1.)

Aggregation

1. Informasi tentang dampak kegiatan bagian fungsional lain terhadap ringkasan laporan keuangan untuk

a. Bagian fungsional Anda.

b. Unit bisnis secara keseluruhan.

2. Informasi dalam bentuk yang memungkinkan Anda untuk melakukan analisis "sensitifitas."

3. Informasi yang menunjukkan pengaruh kejadian pada fungsi yang berbeda, seperti pemasaran atau produksi yang dikaitkan dengan kegiatan atau tugas tertentu Anda.

4. Informasi tentang dampak kejadian pada perioda tertentu, seperti rangkuman informasi bulanan, kuartalan, tahunan, trend, dan perbandingan.

5. Informasi disajikan dalam bentuk yang sesuai dengan model keputusan Anda, seperti:

a. Analisis aliran kas (Discounted cash flow analysis.)

b. Analisis kenaikan laba.

c. Analisis persediaan.

d. Analisis kebijakan kredit.

6. Informasi cost (kos) yang dipisahkan ke dalam komponen tetap dan variabel.

7. Informasi yang disediakan pada bagian-bagian atau wilayah-wilayah fungsional yang berlainan dalam Unit bisnis Anda, seperti pemasaran dan produksi, pusat penjualan, pusat biaya, dan pusat laba.

Integration

1. Informasi yang berkaitan dengan pengaruh yang ditimbulkan oleh keputusan Anda terhadap kinerja bagian fungsional lain.

2. Informasi tentang target yang realistis dan akurat bagi kegiatan seluruh bagian fungsional dalam Unit bisnis Anda.

3. Informasi tentang pengaruh keputusan Anda pada Unit bisnis Anda dan pengaruh keputusan bagian fungsional lain pada bagian fungsional Anda.

\section{Lampiran 2}

Instrumen Intensitas Kompetisi Pasar

Sumber: Chong et al. (2001)

1. Intensitas kompetisi yang dihadapi oleh Unit bisnis Anda di dalam pasar tergantung pada:

a. Jumlah pesaing utama yang beroperasi di dalam pasar.

b. Frekuensi perubahan teknologi dalam industri.

c. Frekuensi pengenalan produk baru.

d. Tingkat pemotongan harga. 
e. Berbagai rangkaian kesepakatan dengan pelanggan jika dibandingkan dengan pesaing.

f. Perubahan kebijakan pemerintah dan pengurangan tarif seperti pajak.

2. Intensitas kompetisi harga yang dihadapi oleh Unit bisnis Anda di dalam pasar (contoh kompetisi harga adalah tingkat pemotongan harga dan berbagai rangkaian kesepakatan seperti termin pembayaran piutang tanpa bunga, pengiriman produk secara cuma-cuma dan bebas biaya garansi, apabila dibandingkan dengan pesaing).

3. Intensitas kompetisi produk (diferensiasi) yang dihadapi oleh Unit bisnis Anda di dalam pasar (contoh kompetisi produk (diferensiasi) meliputi penawaran produk yang lebih baik dibanding dengan produk pesaing berkenaan dengan penyelesaian, pembentukan, ukuran, variasi, ketahanan dan kualitas produk.)

4. Distribusi dan promosi produk serta intensitas kompetisi yang dihadapi oleh Unit bisnis Anda di dalam pasar (contoh kompetisi meliputi usaha untuk mendapatkan saluran distribusi dan promosi yang lebih baik dibanding dengan yang digunakan oleh pesaing.)

\section{Lampiran 3}

\section{Instrumen Kepuasan Kerja}

Sumber: Dewar dan Werbel (1979)

1. Setelah mempertimbangkan semuanya, Saya puas dengan pekerjaan Saya. Secara umum, Saya suka bekerja di Unit bisnis ini.

2. Setelah mempertimbangkan semuanya, Saya puas dengan pekerjaan Saya.

3. Secara umum, Saya suka bekerja di Unit bisnis ini. 